\title{
SEMIÓTICA EM UMA PERSPECTIVA INTERDISCIPLINAR DE ANÁLISE DE TEXTOS
}

\author{
SEMIOTICS IN THE INTERDISCIPLINARY APPROACH OF TEXTS
}

\author{
Márcia Angélica dos Santos \\ UFT - Universidade Federal do Tocantins
}

\begin{abstract}
RESUMO: Este trabalho desenvolve um método interdisciplinar de abordagem de textos, verificando as contribuições da tecnologia e da estatística no desdobramento da análise semiótica de linha francesa. Os dados estatísticos produzidos pela tecnologia pertencem à Tabela de Discriminação de Valores Lexicais, que é parte do instrumental criado por André Camlong (1996), com a colaboração de Thierry Beltran, da Universidade de Toulouse II. Suas informações são geradas por operações matemático-estatísticas, executadas em computador, que transformam os textos em listas de vocábulos devidamente mensurados, o que deixa os dados disponíveis para outros procedimentos, independentes do método Camlong. Para averiguar essa autonomia das informações, relacionam-se os valores da Tabela de Discriminação de Valores Lexicais, com o percurso gerativo de sentido proposto por Algirdas Julien Greimas (1975/1989), composto por três níveis - fundamental, narrativo, discursivo -. As características de cada um desses níveis permitem selecionar determinadas categorias gramaticais e determinados itens lexicais orientadores do desenvolvimento dos níveis e da articulação entre eles. Com essa intersecção interdisciplinar, a investigação conclui que itens lexicais mensurados de acordo o ambiente de que fazem parte constituem subsídios eficazes para a análise greimasiana de textos, assegurando a descrição como científica e tornando válida a metodologia.
\end{abstract}

PALAVRAS-CHAVE: interdisciplinar; computação; estatística; semiótica.

ABSTRACT: This work develops an interdisciplinary approach to the texts, verifying the contributions of the technology and the statistical data in the unfolding of the semiotics analisys according the french line. The statistical data belongs to the Table of Discrimination of Lexical Values, that it is part of the methodology created by Andre Camlong (1996), with the contribution of Thierry Beltran, of the University of Toulouse II. Their informations are produced by mathematicianstatistics operations, executed in computer, that turns the texts into lists of words properly mensured ,which makes the data available to other procedures, independent of the process related to the Camlong method. To inquire this autonomy of the data, the words mensured by the Table of Discrimination of Lexical Values are applied to the generative semiotics created by Algirdas Julien Greimas (1975/1989). In terms of the interdisciplinary, the inquiry concludes that the lexicon organized in bands according to the values acquired in the environment is part constitutes and efficient subsidies for the Greimas' proposal, assuring the description as scientific and certifying its validity in the unfolding of the methodology.

KEYWORDS: interdisciplinary, computation; statistics; semiotics. 


\section{Apresentação}

Em seu livro Elementos de análise do discurso (2005), José Luiz Fiorin define o ato de comunicação como um jogo complexo de manipulação em que, por meio da enunciação, um enunciador pretende fazer o enunciatário crer naquilo que transmite. Há uma performance caracterizada pelo querer fazer e pelo fazer crer subjacentes a procedimentos argumentativos que esse enunciador seleciona e efetivamente emprega para a transmissão de um determinado conteúdo. $\mathrm{O}$ ato de comunicação é, portanto, marcado pela intencionalidade de que inúmeras teorias interpretativas procuram dar conta, tentando explicar, com todo um aparato metodológico, como um texto diz o que diz. Entre essas teorias, citam-se o método matemático-estatístico-computacional, criado por André Camlong (1996), e a abordagem semiótica proposta por Algirdas Julien Greimas (1975/1989).

Presente em todos os campos do conhecimento criados até agora pelo homem, a tecnologia computacional há muito desperta o interesse na área das Letras, inicialmente com suas manifestações mais usuais: cursos em ambiente telemático e a composição do hipertexto. Mas os procedimentos relacionados a computadores progridem, implantando novos formatos às pesquisas e ampliando as propostas interdisciplinares já existentes. $\mathrm{Na}$ análise de textos $\mathrm{e}$ de discursos, as possibilidades de emprego dos computadores distinguem-se quanto às vantagens que oferecem: baseadas em softwares, as iniciativas ajudam a listar, contar e ordenar rapidamente os diversos aspectos de uma reconstrução de textos, assegurando os resultados de procedimentos marcados pelas minúcias do vocabulário, pelo detalhamento sintagmático e pelas ligações das mínimas partes com o todo.

Algumas rotinas evidenciam de imediato certos comportamentos lexicais e discursivos, como demonstra o método desenvolvido com o Stablex, instrumental criado por André Camlong (1996), com a colaboração de Thierry Beltran, pesquisadores do Laboratório de Inteligência Artificial da Universidade de Toulouse II. Nesses anos em que a tecnologia vem interagindo com os estudos lingüísticos e semióticos, o Stablex destaca-se por ser o suporte de um método matemático-estatístico direcionado a textos: juntos, instrumental e método deixam visíveis os procedimentos de desconstrução desses textos em listas, tabelas e gráficos, compondo um banco de informações com propriedades ao mesmo tempo quantitativas e qualitativas. Sua aplicação vale-se de macros e de softwares como o Excel, operados em microcomputadores PCs, estabelecendo uma seqüência mecânica de decomposição imediata dos textos em itens lexicais, acompanhados de valores quantitativos a princípio e qualitativos a seguir.

O método revela, pela análise matemático-estatística, o peso de cada vocábulo na articulação discursiva. Desse modo, os elementos mínimos se organizam de acordo com certas preferências na composição do texto, preferências essas que apontam a tendência do sentido. O método é descritivo, objetivo e indutivo: somente o texto é o elemento considerado para a rotina que, por meio da informática, processa, armazena e recupera dados, deixando evidente a relação entre valores numéricos e ocorrências lexicais. As tabelas e os gráficos derivados revelam as tendências, agrupando-as em categorias. Os valores quantitativos iniciais transformados em valores qualitativos pelos cálculos algébricos que fundamentam algumas tabelas organizam os vocábulos em zonas de preferência, de base e de rejeição quanto ao uso. Essa classificação leva a identificar o tema e, por conseguinte, a orientação do discurso.

O banco de dados fornecido pelos módulos do Stablex coloca em evidência o comportamento dos textos e pode subsidiar os mais variados objetivos. Como todo banco de dados, trata-se de um complexo de informações disponíveis para os mais diferentes fins, o que 
inclui a possibilidade de estabelecer relações com outros métodos: os procedimentos podem ser desenvolvidos a partir das informações organizadas nas tabelas e nos gráficos, e uma delas é o percurso gerativo de sentido proposto por Greimas (1975/1989). Fundamentado em três níveis, o percurso greimasiano pode ser articulado pelo léxico organizado segundo valores, especificamente os valores fornecidos pela Tabela de Discriminação de Valores Lexicais (TDVL), também denominada Léxico Preferencial ou Tabela de Valores Lexicais (ZAPPAROLI/CAMLONG, 2002), em outras aplicações do método. Essa tabela organiza o léxico de cada texto de modo decrescente, segundo o peso (valor) individual do item na composição desse mesmo texto, que o método denomina variável. Para juntar os dois procedimentos, é suficiente tomar os itens lexicais destacados pela Tabela de Discriminação de Valores Lexicais como elementos formadores dos níveis instituídos pela abordagem semiótica de Greimas lembrando, ainda, que ambos os métodos desenvolvem um comportamento comum, pelo qual todas as observações nascem dos próprios textos.

\section{Proposição}

O roteiro que se propõe neste artigo é parte de um trabalho mais abrangente, em que a totalidade do método Camlong não é observada. Entre as diferentes tabelas que o método coloca à disposição para o estudo do texto, são utilizadas no trabalho original a tabela Delta, de Desvios Reduzidos, de Discriminação de Valores Lexicais, de Distribuição de Freqüências e de Lematização. Aqui, serão mencionadas as três primeiras, suficientes para o objetivo, que é demonstrar uma possibilidade de intersecção entre a tecnologia, a estatística e a semiótica.

No desenvolvimento do trabalho original, cumpriram-se as determinações do método Camlong de reunir o mínimo de três textos de um mesmo autor, selecionando seis contos da obra de Guimarães Rosa, para o desdobramento da descrição e da análise. Aqui, pretende-se uma demonstração sintética dessa proposta e, para isso, será focalizado o conto "Esses Lopes", ressaltando que o enfoque se integra a uma abordagem mais extensa. Também é preciso assinalar que, para utilizar os pesos atribuídos pela Tabela de Discriminação de Valores aos itens lexicais, há necessidade de verificar a homogeneidade do corpus escolhido, o que significa testar o equilíbrio lexical dos textos, traduzido pelos índices da Tabela de Desvios Reduzidos (TDR) e pela Tabela de Fisher. Esse procedimento não será exposto aqui, devido à sua extensão. $\mathrm{O}$ que se pretende é apresentar, por meio de um texto extraído de um corpus mais abrangente, a validade de uma proposta interdisciplinar de análise de textos. $\mathrm{Ou}$ seja, demonstrar-se-á que as informações estatísticas, produzidas por um componente do método matemático-estatístico-computacional criado por Camlong para uma abordagem de textos, componente denominado Tabela de Discriminação de Valores Lexicais, constituem um banco de dados privilegiado para elaborar o percurso gerativo de sentido instituído por Greimas.

\section{Fundamentos teóricos}

A Tabela de Discriminação de Valores Lexicais do método Camlong (1996), que também será indicada com a sigla TDVL, é a base dos procedimentos desenvolvidos, pois traz todas as informações necessárias: individualiza e identifica os itens lexicais da variável considerada, informa a freqüência e o peso de cada vocábulo nas relações que mantêm na variável de que faz parte e no corpus escolhido, compondo uma hierarquia lexical segundo esses valores. Os itens lexicais são considerados pelo valor que adquirem em relação aos 
outros itens, no texto e no corpus de que fazem parte. Orientando quanto ao uso privilegiado ou não de cada item na articulação dos textos e dos discursos, a TDVL é a escolha natural para uma relação com outras propostas de análise voltadas para o sentido. $\mathrm{Na}$ abordagem semiótica com base em Greimas (1975/1989), o roteiro é marcado pelos itens lexicais mínimos, em contraste, em contradição ou em complementaridade; pelos estados e transformações de estados, expressos em programas narrativos com as conseqüentes destinações e manipulações, pelas debreagens da enunciação e por figuras e temas que constroem o simulacro do mundo. Para o desenvolvimento desse percurso gerativo, utilizamse sobretudo as obras de José Luiz Fiorin (2005), Diana Luz Pessoa de Barros (1988/1990) e A. J. Greimas (1975/1989) e, para a interpretação das figuras discursivas, há acentos da simbologia antropológica de Gilbert Durand (1997).

Situando-se entre a estatística produzida pela tecnologia e a semiótica, a posição adotada tem como princípio os limites do texto, ou seja, somente as informações geradas por ele orientam os procedimentos.

\section{Seleção do corpus}

Para demonstrar as possibilidades de intersecção entre os tópicos teóricos considerados, focaliza-se um dos seis contos de Guimarães Rosa reunidos na proposta original: o conto "Esses Lopes", pertencente à obra Tutaméia (1967, pp. 45-48), cujas partes citadas neste artigo têm a referência aos parágrafos, a fim de tornar mais rápida a localização de recortes ou de vocábulos mencionados na descrição e na análise.

$\mathrm{Na}$ seleção do corpus original, delimitou-se o procedimento a textos em que o enunciador, realizando debreagens e embreagens, privilegia um narrador também actante, que, por sua vez, é revestido por um ator, interlocutor ou não. Na variável Esses Lopes, ao narrador actante se superpõe, no nível discursivo, a figura de uma mulher justiceira, ressaltando que essa caracterização é inferida; não é declarada pelo narrador. Em tom de denúncia, essa mulher justiceira estimula a reflexão sobre valores criados pelo homem. Seu trânsito acontece no ambiente rural, uma vez que há citação de espaços como ribeira e terreiro (ROSA, 1967, pp. 45 e 47, parágrafos 5 e 19). Seu relato traz a oscilação entre o momento presente da enunciação e o pretérito dos acontecimentos.

\section{Descrição e análise da variável}

\subsection{Tabela de discriminação de valores lexicais (TDVL)}

A variável possui 623 vocábulos, que a TDVL organiza segundo o peso que obtêm quando relacionados ao texto e ao corpus considerado:

\begin{tabular}{|c|l|c|c|c|}
\hline & TDVL & Esses & Lopes & \\
\hline & & $\mathrm{p}$ & 0,131 & \\
\hline & & $\mathrm{q}$ & 0,869 & \\
\hline Ordem & $\begin{array}{l}\text { Item } \\
\text { Lexical }\end{array}$ & Corpus & $\begin{array}{l}\text { Esses } \\
\text { Lopes }\end{array}$ & Peso/Valor \\
\hline 1 & lopes & 10 & 10 & 8,148 \\
\hline 2 & nicão & 3 & 3 & 4,463 \\
\hline 3 & sertório & 3 & 3 & 4,463 \\
\hline 4 & preta & 3 & 3 & 4,463 \\
\hline 5 & filhos & 5 & 4 & 4,436 \\
\hline
\end{tabular}




\begin{tabular}{|c|l|c|c|c|}
\hline 6 & quero & 5 & 4 & 4,436 \\
\hline 621 & a & 206 & 17 & $-2,058$ \\
\hline 622 & não & 155 & 9 & $-2,688$ \\
\hline 623 & se & 181 & 8 & $-3,458$ \\
\hline
\end{tabular}

Os itens lexicais organizados segundo o valor ou peso, do maior para o menor, traduzem a importância de cada um na articulação discursiva. A tabela apresenta, então, uma primeira faixa com o léxico preferencial, ou seja, os vocábulos com valor substancial, igual ou acima de 1,96. A variável "Esses Lopes" possui 352 vocábulos dentro dessa faixa privilegiada, que pode ser examinada nos anexos deste artigo. Entre esses vocábulos preferenciais, importam sobretudo os que carregam traços nocionais, como, por exemplo, Lopes ou quero. As duas colunas relacionadas à freqüência dos vocábulos - as colunas denominadas Total, com totais obtidos no corpus, e Esses Lopes, com a freqüência específica da variável em análise - revelam os vocábulos exclusivos dessa variável, quando os valores são iguais, e aqueles que não são exclusivos da variável, portanto aparecem em outras variáveis do corpus selecionado, quando os valores divergem. Como exemplo da primeira ocorrência, há o item Lopes, com a freqüência 10 em ambas as colunas e, como ilustração da segunda possibilidade, cita-se o item quero com a freqüência 5 no corpus e 4 na variável. A última coluna mostra o peso de cada vocábulo, ou seja, a sua importância para a articulação do texto e do discurso em análise. No que se refere aos vocábulos já citados, Lopes possui o valor 8,148 e quero tem o peso de 4,436 como demonstrativo de sua importância.

Ainda dentro dessa faixa preferencial, acham-se os hápax, vocábulos com uma única ocorrência, sendo, portanto, exclusivos da variável em que aparecem. $\mathrm{O}$ fato de terem o peso acima do valor mínimo preferencial aponta sua importância na variável. Em "Esses Lopes", há 313 hápax, do número de ordem 28 ao 341 da TDVL, destacando-se a igualdade de freqüência 1 entre as colunas Total e Esses Lopes, que os identifica como hápax, e o peso significativo de 2,577 mostrado na última coluna.

A TDVL possui outras faixas de vocábulos, reunidos segundo a sua importância: a zona intermediária corresponde ao vocabulário básico, subdividido em uma zona com tendência positiva e uma zona com tendência negativa. Trata-se do vocabulário de emprego corrente no sentido de formar o sustentáculo do discurso. Os essencialmente básicos têm o peso centrado em torno da média $-1 \leq Z \leq+1$, sendo indispensáveis à formação do texto e à delimitação específica da zona centrada no vocabulário comum. $\mathrm{O}$ vocabulário básico com tendência positiva, entre $+1 \leq \mathrm{Z} \leq+2$, tem alguns referenciais temáticos; 0 vocabulário básico com tendência negativa, entre $-2 \leq Z \leq-1$, contém mais itens responsáveis pela articulação e, grosso modo, sem referenciais temáticos. Situando-se além dos dois pontos negativos, o léxico diferencial é aquele cujo valor indica abandono ou rejeição, opondo-se ao preferencial enquanto carga de expressividade temático-discursiva. Dependendo da análise considerada, pode ser altamente significativo para o texto focalizado. Nesta análise, será destacado o maior valor diferencial, - 3,458 do pronome se.

\begin{tabular}{|c|l|c|c|c|}
\hline Ordem & $\begin{array}{l}\text { Item } \\
\text { Lexical }\end{array}$ & Corpus & $\begin{array}{l}\text { Esses } \\
\text { Lopes }\end{array}$ & Peso/Valor \\
\hline$(\ldots)$ & & & & \\
\hline 623 & se & 181 & 8 & $-3,458$ \\
\hline
\end{tabular}


Ocupando a faixa diferencial, o valor desse item aponta uma rejeição a todas as nuances de significado que possam instalar-se no discurso, incluindo a indeterminação de pessoa. $\mathrm{O}$ valor negativo quanto ao emprego da indeterminação que, de acordo com Fiorin (2002), pode englobar a primeira pessoa, aponta a busca da individualidade em detrimento da anulação do ser.

\subsection{Procedimentos gerais}

Para a seleção de itens orientadores do sentido dentro da TDVL, é levada em conta a faixa essencialmente preferencial, com a identificação dos vocábulos de maior valor. Parte-se desses itens e de suas relações com os demais itens lexicais preferenciais, para estabelecer, por meio da análise de recortes do texto, as relações que levam a fundamentar a sintaxe e a semântica dos níveis profundo, narrativo e discursivo.

No que se refere ao nível discursivo, a actorialização pede foco na flexão verbal em pessoa e na utilização dos pronomes pessoais e de tratamento. A temporalização depende dos tempos verbais com maior valor e com maior incidência. A espacialização leva a referências espaciais figurativas como ribeira ou terreiro. Não havendo nenhum desses índices em evidência, identificam-se as debreagens por meio da extração de recortes discursivos associados aos vocábulos de maior peso. É preciso lembrar que a actorialização, quando desenvolve a debreagem enunciativa da enunciação já pressupõe um espaço aqui e o tempo do agora, enquanto a debreagem enunciva da enunciação constitui o espaço lá e o tempo de então, que podem ser ratificados pelos recortes discursivos.

$\mathrm{O}$ estrato básico e o diferencial são examinados naquilo que os ligam ao percurso gerativo de sentido, como pronomes pessoais identificadores da actorialização, o tempo das formas verbais, índices da temporalização e as figurativizações, reveladoras do espaço.

Quanto às classes gramaticais, são considerados os vocábulos nocionais substantivo, adjetivo, verbo - e pronomes pessoais - reto, oblíquo e de tratamento pertencentes à faixa preferencial. Nessa seleção, o vocábulo, enquanto item do léxico, é tratado como complexo narrativo em potencial, atualizado segundo a voz de quem o emprega, o contexto no qual é utilizado e as relações que mantêm com os outros itens da construção discursiva. Geralmente, a lista de vocábulos preferenciais, ao identificar os itens de maior peso positivo, permite, por meio deles, desenvolver todo o complexo descritivo e analítico do sentido, bastando identificar, com o auxílio dos recortes discursivos, a direção tomada.

Quanto às outras classes, as palavras relacionais, bem como os advérbios, os numerais, os artigos. Os pronomes indefinidos, demonstrativos e possessivos só são considerados quando estabelecerem, no discurso, uma relação fundamental com as categorias já destacadas.

\subsection{Procedimentos específicos}

Os procedimentos específicos dizem respeito às descrições das ocorrências relacionadas aos níveis do percurso gerativo de sentido. Na introdução de cada variável, as denominações utilizadas pertencem ao método Camlong; na descrição do percurso gerativo, a denominação item lexical é substituída por figura, quando pertinente, e seus pesos, dados pelo léxico preferencial, são mencionados quando necessário. Os textos são tratados como variáveis durante toda a descrição e a análise. 


\subsection{Aplicação}

Na variável Esses Lopes, o item lexical de maior peso, segundo a TDVL, é o patronímico Lopes, com o valor positivo de 8,148.

\section{Nível fundamental do percurso gerativo de sentido}

O destaque de valor dado ao item Lopes leva às extrações pertinentes, em que os recortes obtidos instalam "dominação", como um dos termos das categorias do nível fundamental, evidenciado sobretudo em tomavam, mandavam, donos, nenhum capim, nenhum leite:

\footnotetext{
Esses Lopes, raça, vieram de outra ribeira, tudo adquiriam ou tomavam; não fosse Deus, e até hoje mandavam aqui, donos. (ROSA, 1967, p. 45, parágrafo 5)

Esses Lopes! - com eles, nenhum capim, nenhum leite. (ROSA, 1967, p. 46, parágrafo 8)
}

Lopes aponta o percurso de um poder visto negativamente, que se ratifica com a apreciação manifestada inicialmente pelo sujeito Flausina em "Má gente, de má paz; deles, quero distantes léguas."(ROSA, 1967, p. 45, parágrafo 1) e também no desfecho do relato, em "Todo o mundo vive para ter alguma serventia. Lopes não! - desses me arrenego." (ROSA, 1967, p. 48, p. 22).

Mas um termo não se instala sozinho, constitui de imediato sua oposição, representada por liberdade, que se evidencia no primeiro parágrafo: "Livre, por velha nem revogada não me dou, idade é a qualidade.” (ROSA, 1967, p. 45, parágrafo 1)

Outras ocorrências colaboram para que os termos liberdade e dominação sejam articuladores fundamentais do sentido desta variável: a presença da primeira pessoa, representada por me, com peso altamente significativo na TVDL, sinaliza a expressiva participação, no nível discursivo, de um ator que se diz alvo de um processo, ou que desenvolve a ação voltada para si, ou ambos.

No plano fundamental, a determinação desses modos de presença é importante para ratificar a oposição e também o revestimento valorativo dos termos. Lopes, enquanto desencadeador de uma isotopia da dominação rejeitada, já se configura como disfórico.

Excluindo a ocorrência em - "Despois da missa de mês, me espera..." (ROSA, 1967, p. 47, parágrafo 16), pertencente a um locutor, identificado como Nicão no trecho que antecede essa fala ("Nicão, um, mau me emprazou:", ROSA, 1967, p. 47, parágrafo 16), os enunciados em que o narrador se diz alvo por meio do pronome me - me pegou, me levou, me vigiar, me davam, me requerendo, me emprazou, me viu, me botou - superam os demais. Essa incidência aponta a sujeição, a submissão a alguém ou a algo, ou a ambos, ratificada pelo comentário "Anos, que me foram, de gentil sujeição, custoso que nem guardar chuva em cabaça, picar fininho a couve." (ROSA, 1967, p.47, parágrafo 16).

Em uma extração geral, voltada para a primeira pessoa, esses enunciados relacionam-se com "Eu queria me chamar Maria Miss, reprovo meu nome, de Flausina." (ROSA, 1967, p. 45, parágrafo 2), determinando que sujeição e fazer reflexivo ligam-se, no nível do discurso, à figura de Flausina, o mesmo sujeito que avalia negativamente os Lopes. Ao afirmar, no início de seu relato, no tempo do agora, "Livre, por velha nem revogada não me dou," (ROSA, 1967, p.45, parágrafo 1), que se opõe a "A gente, eu, delicada moça, cativa assim, com o abafo daquele" (ROSA, 1967, p.46, parágrafo 10), pertencente ao tempo do 
então, ratifica liberdade x dominação como categorias de base. Do ponto de vista de Flausina, a primeira é eufórica, a segunda é disfórica.

A sintaxe do nível fundamental baseia-se na afirmação e na negação das categorias de base. No quadrado semiótico, a S1 se atribui o termo liberdade, o que coloca dominação em S2, definindo semanticamente as operações fundamentais que vão impulsionar o percurso gerativo desta variável: da dominação em um tempo passado para a liberdade no tempo concomitante.

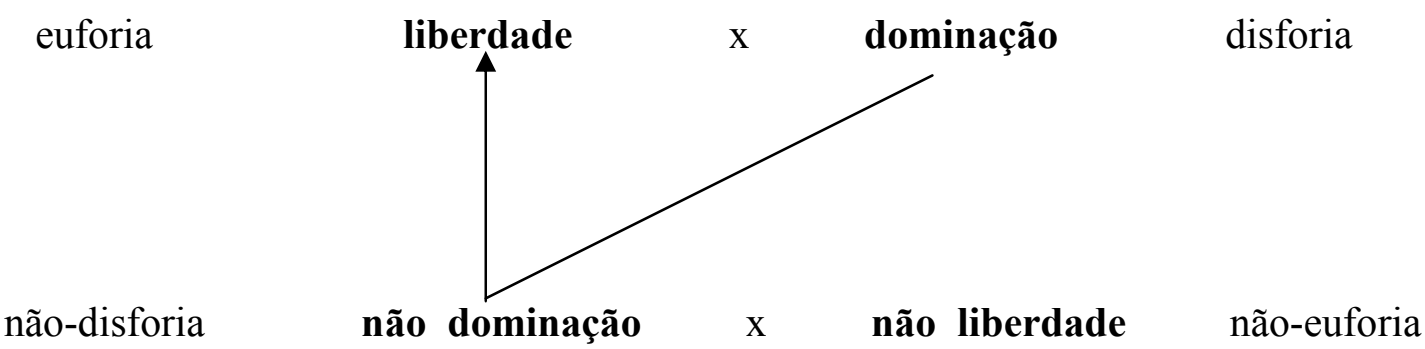

Disforia: dominação

Não-disforia: não-dominação

euforia: liberdade

Negar a dominação significa afirmar a liberdade. Esse percurso está sintetizado nos seguintes recortes:

-dominação - "Mas, primeiro, os outros obram a história da gente.” (ROSA, 1967, p.45, parágrafo 2)

-não-dominação - "Me viu e me botou na cabeça. Aceitei, de boa graça, ele era o aflitinho dos consolos.” (ROSA, 1967, p. 47, parágrafo 19)

-liberdade - "Livre, por velha nem revogada não me dou," (ROSA, 1967, p. 45, parágrafo 1)

As determinações do nível fundamental, vistas em um plano mais geral, fazem identificar um enunciador que euforiza a liberdade e coloca em disforia os valores da dominação, do poder cruel e devorador que amesquinha os seres, depreendido das apreciações atribuídas aos Lopes por Flausina. Essa visão negativa já se revela no patronímico Lopes, enquanto semema relacionado à figura do lobo pois, segundo Gilbert Durand (1997) desde antiquíssimas civilizações, carrega a simbologia do mal. Pode-se dizer que, no nível fundamental, já se inscreve um enunciador e um ethos, com um tom contrário a um poder insensível e exploratório, e defensor da liberdade.

\section{Nível narrativo}

O alvo da dominação, o sujeito Flausina, não se submete aos Lopes. Elabora e executa seu programa de libertação, evidenciando na narrativa o caminho da negação e asserção dado pelo nível fundamental. A sucessão dos fatos a partir do tempo passado mostra as transformações por que passa a vida de Flausina. Como o nível narrativo pode ser construído com dois enunciados mínimos: o da falta e o da liquidação da falta, nessa narrativa, o sujeito Flausina está em disjunção com o objeto-valor liberdade ("o querer outras 
larguras.”, ROSA, 1967, p. 46, parágrafo 10), enquanto se relaciona com os homens da família Lopes. Após uma série de enunciados de fazer, constituintes do programa de liquidação da falta, Flausina tem seu estado alterado, chegando à conjunção com o seu objeto-valor:

Livre, por velha nem revogada não me dou, (ROSA, 1967, p. 45, parágrafo 1)

O povo ruim terminou, aqueles. (ROSA, 1967, p. 48, parágrafo 21)

$\mathrm{Na}$ execução do programa, Flausina, enquanto sujeito-destinador, manipula os actantes figurativizados pelos homens da família Lopes, ou seja, manipula a instância do poder com um jogo de sedução, tentação e provocação.

- sedução:

Falei, quando dinheiro me deu, afetando ser bondoso:

- "Eu tinha três vinténs, agora tenho quatro..." Contentado ele ficou, não sabia que eu estava abrindo e medindo. (ROSA, 1967, p.46, parágrafo 8)

Anos, que me foram, de gentil sujeição, custoso que nem guardar chuva em cabaça, picar fininho a couve. (ROSA, 1967, p. 47, parágrafo 16)

E, este, bem demais e melhor tratei, seu desejo efetuado. (ROSA, 1967, p.47, parágrafo 19)

tentação: "Sorria debruçada em janela, no bico do beiço, negociável justiçosa." (ROSA, 1967, p. 47, parágrafo 18)

-provocação: - “De hoje por diante, só muito casada!” (ROSA, 1967, p. 47, parágrafo 19).

Esse jogo corre paralelo às articulações desenvolvidas pelo poder com o qual interage, pois os Lopes tentam pelo dinheiro e intimidam pela ação:

Falei, quando dinheiro me deu, afetando ser bondoso: (ROSA, 1967, p.46, parágrafo 8).

Para me vigiar, botou uma preta magra em casa, (ROSA, 1967, p. 46, parágrafo 9).

Para atuar como sujeito-destinador, é preciso um saber fazer que Flausina obtém, enquanto se relaciona com os Lopes:

Mais aprendi lição de ter juízo. Calei muitos prantos. Agüentei aquele caso corporal. (ROSA, 1967, p. 45, parágrafo 7)

Fiz que quis: saquei malinas lábias. (ROSA, 1967, p. 46, parágrafo 8)

Entendi: a que eu tinha de engambelar, por arte de contas; (...) Regi de alisar por fora a vida. (ROSA, 1967, p. 46, parágrafo 9)

Tracei as letras. Carecia de ter o bem ler e escrever, conforme escondida.

Isso principiei - minha ajuda em jornais de embrulhar e mais com as crianças de escola. (ROSA, 1967, p. 46, parágrafo 11)

Virei cria de cobra. (ROSA, 1967, p. 46, parágrafo14)

Padeci com jeito. (ROSA, 1967, p. 47, parágrafo 16)

Até que aquela idéia endurecesse. (ROSA, 1967, p. 47, parágrafo 18)

Por isso, andei quebrando metade da cabeça: (ROSA, 1967, p. 47, parágrafo 20) 
Flausina passa do estado de disjunção para o estado de conjunção pragmática com a liberdade, com que já se encontrava em conjunção cognitiva.

-disjunção pragmática:

O homem me pegou, com quentes mãos e curtos braços, me levou para uma casa, para a cama dele. (ROSA, 1967, p. 45, parágrafo 7)

de se estar noite inteira em canto de catre, com o volume do outro cercando a gente, [...] Eu ficava espremida mais pequena, (ROSA, 1967, p. 46, parágrafo 10)

-disjunção pragmática, conjunção cognitiva com a liberdade:

na parede minha unha riscava rezas, o querer outras larguras. (ROSA, 1967, p. 46, parágrafo 10)

Mexi em vão por me soltar, dessas minhas pintadas feras. [...] Anos, que me foram, de gentil sujeição, custoso (ROSA, 1967, p. 47, parágrafo 16)

Aceitei, de boa graça, ele era o aflitinho dos consolos. (ROSA, 1967, p. 47, parágrafo 19)

-não-disjunção pragmática:

Mais, enfim que o filho dele nasceu, agora já tinha em mim a confiança toda, quase. (ROSA, 1967, p. 46, parágrafo 13)

-conjunção pragmática com a liberdade:

Livre, por velha nem revogada não me dou, (ROSA, 1967, p. 45, parágrafo 1)

A semântica narrativa revela os valores inscritos nos objetos que se dividem em objetos modais e objetos de valor. Os objetos modais são representados pelo querer, dever, poder e saber. Os objetos de valor são aqueles com os quais os sujeitos entram em conjunção ou em disjunção.

Para o sujeito Flausina, o objeto-valor é a liberdade, o objeto modal é poder ser. Em seu tempo de então, Flausina queria, mas não podia libertar-se dos Lopes. Adquirindo a competência em sucessivas narrativas modalizadas pelo querer e realizando a performance em narrativas em que o querer e o não poder não fazer se sobrepõem às interdições, ela entra em conjunção com o objeto-valor, expresso no trecho "Quero falar alto." (ROSA,1967, p. 45, parágrafo 1), em que o presente do indicativo do verbo aponta a continuidade. Para agir, Flausina precisou valer-se do parecer em detrimento do ser:

-parecia ser: "Contentado ele ficou, não sabia que eu estava abrindo e medindo. (ROSA, 1967, p. 46, parágrafo 8)

-parecia querer: "Fiz que quis: saquei malinas lábias.” (ROSA, 1967, p.46, parágrafo 8)

-parecia aceitar: Carecia de ter o bem ler e escrever, conforme escondida. (ROSA, 1967, 46, parágrafo 11) 
Anos, que me foram, de gentil sujeição, custoso que nem guardar chuva em cabaça, picar fininho a couve. (ROSA, 1967, p. 47, parágrafo 16)

Deixo de porfias, (ROSA, 1967, p. 48, parágrafo 21)

-parecia lamentar: "Inconsolável chorei, conforme os costumes certos," (ROSA, 1967, p. 47, parágrafo 18)

\section{O querer de Flausina é expresso em:}

-querer ter:

o querer outras larguras. (ROSA, 1967, p.46, parágrafo 10)

E o governo da vida? (ROSA, 1967, p. 47, parágrafo 16)

Quero o bom-bocado que não fiz, (ROSA, 1967, p. 48, parágrafo 22)

-querer ser: "Livre, por velha nem revogada não me dou, [..] Meu gosto agora é ser feliz," (ROSA, 1967, p. 45, parágrafo 1)

-querer fazer: "Quero falar alto.” (ROSA, 1967, p. 45, parágrafo 1)

A aparente aceitação de Flausina em relação aos Lopes não se deve somente ao fato de se achar indefesa no tempo de então; a desvalorização social leva-a a detectar, progressivamente, a possibilidade de operar uma alteração em seu estado de pobreza, justificando as ações como reflexo da mesma violência, da mesma insensibilidade de que foi alvo:

- percepção de que a situação social se sobrepõe a outros valores - "Só que o que mais cedo reponta é a pobreza." (ROSA, 1967, p. 45, parágrafo 3)

-vulnerabilidade - "Mãe e pai não deram para punir por mim." (ROSA, 1967, p. 45, parágrafo 5)

- impotência diante de um poder insensível, violento: Tive algum? Cortesias nem igreja. O homem me pegou, com quentes mãos e curtos braços, me levou para uma casa, para a cama dele. (ROSA, 1967, p. 45, parágrafo 7)

-percepção de possíveis transformações de estado - "saquei malinas lábias." (ROSA, 1967, p.46, parágrafo 8)

-percurso de liquidação da falta - "E dê-cá dinheiro.” (ROSA, 1967, p. 46, parágrafo 12)

-justificação das ações com a violência sofrida - "Por sopro do demo, se vê, uns homens caçam é mesmo isso, que inventam.” (ROSA, 1967, p. 46, parágrafo 8)

-justificação das ações como reflexo de uma interação - "Aquilo tange as canduras de noiva, pega feito doença, para a gente em espírito se traspassa." (ROSA, 1967, p. 46, parágrafo 10)

-liquidação da falta material - "Daí, tudo tanto herdei, até que com nenhum enjôo." (ROSA, 1967, p. 47, parágrafo 20) 
Para a consecução de seu programa narrativo de base, Flausina vale-se do parecer em detrimento do ser, caracterizador dos programas narrativos de uso. Esse aspecto indica a probabilidade de uma frustração, que já se delineia em "Tão certo como eu hoje estou o que nunca fui." (ROSA, 1968, p. 46, parágrafo 10), com o emprego do verbo estar, portador da transitoriedade, em oposição ao verbo ser, indicativo do estado permanente.

A manipulação por sedução e por provocação que encobre um querer intenso voltado para a aquisição da liberdade e também para os valores materiais do outro, cria um efeito de estranhamento e irradia um tom de manipulação por provocação do enunciador em relação a seu co-enunciador, no sentido de que sejam observadas as falas e as ações dos sujeitos envolvidos nos episódios.

Por sopro do demo, se vê, uns homens caçam é mesmo isso, que inventam. (ROSA, 1967, p. 46, parágrafo 8)

\section{Nível discursivo}

\section{Actorialização}

A articulação em primeira pessoa aqui se destaca com os valores preferenciais das formas me $(2,675)$, meus $(3,456)$, quero $(4,436)$, achei $(3,644)$, amo $(3,644)$. Quanto à inserção no discurso:

-me relaciona-se a verbos flexionados na primeira e na terceira pessoa:

não me dou, [...] Lopes nenhum me venha, (ROSA, 1967, p. 45, parágrafo1)

me via vestida de flores. [...] Me valia ter pai e mãe, [...] sem da inocência me destruir, [...] Eu queria me chamar Maria Miss, (ROSA, 1967, p. 45, parágrafo 3)

Deus me deu [...] Me olhava: aí eu espiada e enxergada no ter de me estremecer. (ROSA, 1967, 45, parágrafo 4)

O homem me pegou, [...] me levou para uma casa, (ROSA, 1967, p.45, parágrafo 7)

quando dinheiro me deu, (ROSA, 1967, p. 46, parágrafo 8)

Para me vigiar, (ROSA, 1967, p. 46, parágrafo 9)

ele me enriquecia. (ROSA, 1967, p. 46, parágrafo 13)

E os Lopes me davam sossego? (ROSA, 1967, p. 47, parágrafo 15)

Dois deles, tesos, me requerendo, [...] Nicão, um, mau me emprazou: [...] Anos, que me foram, de gentil sujeição, (ROSA, 1967, p. 47, parágrafo 16)

ainda me sobrou: [...] Me viu e me botou na cabeça. (ROSA, 1967, p. 47, parágrafo 19)

menos me falem, [...] sou de me constar em folhinhas e datas? (ROSA, 1967, p. 48, parágrafo 21)

me venham filhos, [...] De que me adianta estar remediada e entendida, (ROSA, 1967, p. 48, parágrafo 22)

\footnotetext{
- meus ocorre em:
}

Mesmo de meus filhos, os três. (ROSA, 1967, p. 45, parágrafo 1)

Se enfrentaram, bom contra bom, meus relâmpagos, a tiros e ferros. (ROSA, 1967, p. 47, parágrafo 18) 
Meus filhos, Lopes, também, provi de dinheiro, (ROSA, 1967, p. 48, parágrafo 21)

-a forma verbal quero caracteriza os seguintes enunciados:

deles, quero distantes léguas, [...] Quero falar alto. (ROSA, 1967, p. 45, parágrafo 1)

Quero o bom-bocado que não fiz, quero gente sensível! (ROSA, 1967, p. 48, parágrafo 22)

-a forma verbal achei ocorre em:

Ainda achei o fundo do meu coração. (ROSA, 1967, p. 45, parágrafo 1)

Deixo de porfias, com o amor que achei. (ROSA, 1967, p. 48, parágrafo 21)

-a forma verbal amo ocorre em:

Amo um homem, (ROSA, 1967, p. 45, parágrafo 1)

Amo, mesmo. (ROSA, 1967, p. 48, parágrafo 21)

Com essas determinações, pode-se constatar que ocorre a debreagem enunciativa da enunciação instalando um eu narrador. A presença da primeira pessoa mostra também a identidade desse narrador com um dos actantes da narrativa, criando efeitos de subjetividade. No nível figurativo, o eu narrador e o actante reúnem-se em Flausina e sua corporalidade madura, identificada nos trechos "Livre, por velha nem revogada não me dou, idade é a qualidade." (ROSA, 1967, p.45, parágrafo 1); "Que podia ser mãe dele, menos me falem, sou de me constar em folhinhas e datas?" (ROSA, 1967, p. 48, parágrafo 21). Essas informações ratificam-se quando, por meio da debreagem enunciativa do enunciado, Flausina, como narrador actante, relata um tempo passado, o tempo em que era menina e mocinha, no qual se retrata delicada, inocente, inofensiva e indefesa:

Eu era menina, me via vestida de flores. [...] Mocinha fiquei, sem da inocência me destruir, tirava junto cantigas de roda e modinhas de sentimento. (ROSA, 1967, p.45, parágrafo 3)

Para o narrador actante Flausina, é a chegada dos Lopes que gera a transformação no seu modo de ser. Por uma debreagem enunciva do enunciado, que cria um efeito de distanciamento, esse narrador actante retrata o poder, a violência e a insensibilidade dos Lopes:

E veio aquele, Lopes, chapéu grandão, aba desabada. Nenhum presta; mas esse, Zé, o pior, rompente sedutor. (ROSA, 1967, p. 45, parágrafo 4)

Esses Lopes, raça, vieram de outra ribeira, tudo adquiriam ou tomavam; não fosse Deus, e até hoje mandavam aqui, donos. (ROSA, 1967, p. 45, parágrafo 5)

$\mathrm{O}$ efeito de distanciamento tem marcas enfáticas de subjetividade, à medida que a referência aos Lopes é feita com os pronomes esse, esses, aquele, traduzindo e reforçando a aversão. Esse tom de rejeição também é dirigido à própria Flausina e pode ser detectado na debreagem de segundo grau, quando, como narradora, cede a voz a si mesma, no 
tempo não-concomitante (ROSA, 1967, pp. 46 e 47, parágrafos 8 e 19). As falas têm tripla marcação: além dos dois pontos e do travessão, as aspas diferenciam a interlocução, indicando um absoluto distanciamento entre a Flausina do presente, desvinculado dos Lopes, e a do passado, ligado aos Lopes, rompendo assim qualquer identidade ou identificação. Esse distanciamento se faz presente ainda na ocorrência do discurso citante e do discurso citado, em que também se nota a atitude de denúncia: não havendo o diálogo, a palavra não é assumida, privilegiando a expressão "falso alegado". Embora haja dois pontos, o uso do verbo no pretérito imperfeito identifica o discurso como citado, a fala apenas mencionada dilui-se e prevalece a análise da interlocução da Flausina jovem feita pela Flausina madura:

Mandou embora a preta Si-Ana, quando levantei o falso alegado: que ela alcovitava eu cedesse vezes carnais a outro, (ROSA, 1967, p. 46, parágrafo 13)

Essas ocorrências vão delineando um narrador actante que rejeita e denuncia não só os Lopes, como também a si mesmo, enquanto se reveste da figura de Flausina em relação com os Lopes. Para estimular o narratário a essa percepção, utiliza frases indagativas, para as quais não espera resposta e sim atenção maior. Em algumas dessas indagações, desconstrói consensos culturais e morais, ao mesmo tempo que procura justificar o fazer realizado, o que cria o paradoxo, pois minimiza a ação com avaliações que contradizem o consenso moral:

-desconstrução de consensos culturais e morais relativos às figuras mencionadas:

Me valia ter pai e mãe, sendo órfã de dinheiro?(ROSA, 1967, p. 45, parágrafo 3)

Ao Sertório dei mesmo dois filhos? Total, o quanto que era dele, cobrei, passando ligeiro para as minhas posses; até honra. (ROSA, 1967, p. 47, parágrafo 17)

-justificativas:

Tive algum? Cortesias nem igreja. (ROSA, 1967, p. 45, parágrafo 7) A gente, eu, delicada moça, cativa assim, com o abafo daquele, sempre rente, no escuro. [...] sei as perversidades que roncava? (ROSA, 1967, p. 46, parágrafo 10)

E os Lopes me davam sossego? (ROSA, 1967, p. 47, parágrafo 15)

E o governo da vida? (ROSA, 1967, p.47, parágrafo 16)

sou de me constar em folhinhas e datas? (ROSA, 1967, p. 48, parágrafo 21)

-frustração:

De que me adianta estar remediada e entendida, se não dou conta da questão das saudades? (ROSA, 1967, p. 48, parágrafo 22)

As indagações que assumem valor argumentativo e que não esperam resposta também podem ser vistas como uma sanção negativa em relação ao saber do narratário, minimizando qualquer avaliação por parte deste: esse traço é demonstrado pela generalização feita em "Ninguém põe idéia nesses casos:" (ROSA, 1967, p.46, parágrafo 10), quando nega a competência do narratário para avaliar. 
Algumas vezes, o narrador actante emprega a expressão a gente, diluindo as fronteiras com o narratário e neutralizando as pessoas. Esse mecanismo de embreagem rompe os limites enunciativos e atinge a enunciação: a expressão a gente envolve o par enunciador/co-enunciador, configurando, enquanto emissão do enunciador, uma espécie de arremedo irônico e um processo de conscientização sobre a contradição entre consensos culturais e ação:

-afirmação sobre a impotência do seres: "Mas, primeiro, os outros obram a história da gente." (ROSA, 1967, p. 45, parágrafo 2)

-arremedo de impotência, com ironia concentrada em delicada moça, à medida que o enunciador expressa inicialmente o enunciado, o que pode ser inferido pela expressão a gente, instalando-o a seguir no nível narrativo:

A gente, eu, delicada moça, cativa assim, com o abafo daquele, sempre rente, no escuro. (ROSA, 1967, p. 46, parágrafo 10)

A ambivalência de Flausina, exposta em outras afirmações soa, na voz do enunciador, como arremedo, o que leva à reflexão sobre consensos morais e estereótipos culturais: "A gente tem é de ser miúda, mansa, feito botão de flor." (ROSA, 1967, p. 45, parágrafo 5).

A debreagem actancial aponta até agora para um efeito de distanciamento em relação aos Lopes e ao fazer desenvolvido por Flausina, enquanto interage com os Lopes. Nesse processo, ao mesmo tempo em que o narrador actante procura estimular a atenção do narratário para certos tópicos, sobretudo os paradoxais, abafa-lhe a voz com avaliações negativas de sua competência. A expressão a gente não indica proximidade, mas a presença de um enunciador que envolve o enunciatário em um processo de conscientização: há ironia em relação a consensos culturais, à medida que estabelece a contradição entre a ação e as palavras de Flausina, o que faz emergir uma figura feminina desprovida da caracterização e da integridade convencionadas por determinadas coletividades.

tudo adquiriam ou tomavam; não fosse Deus, e até hoje mandavam aqui, donos. A gente tem é de ser miúda, mansa, feito botão de flor. (ROSA, 1967, p. 45, parágrafo 5)

\section{Temporalização}

$\mathrm{Na}$ zona preferencial, acha-se a forma quero, que leva a duas extrações do primeiro parágrafo: "Má gente, de má paz; deles, quero distantes léguas" e "Quero falar alto" (ROSA, 1967, p.45). Inserindo essas extrações nesse mesmo parágrafo, nota-se a ocorrência de outras formas preferenciais - dou; é; amo; vive; escorraço; há - projetando a construção narrativa com o predomínio do tempo presente. A debreagem temporal acomoda, portanto, um tempo do agora, um tempo concomitante, sinalizando o sistema temporal enunciativo da enunciação, com o uso do presente do indicativo. Essa debreagem enunciativa de primeiro grau abre-se para o então: por uma debreagem interna cria-se a não-concomitância, figurativizada no relato do passado de Flausina.

Meu gosto agora é ser feliz no sofrer e no regalo. (ROSA, 1967, p.45, parágrafo 1) 
Eu era menina, me via vestida de flores. (ROSA, 1967, parágrafo 3)

Nessa base, inserem-se outros tempos, entre os quais será destacado o presente gnômico que marca o retorno à instância da enunciação, inserindo o par enunciador/coenunciador. O presente omnitemporal é gerado pelo mecanismo da embreagem, uma vez que suspende o tempo da narrativa. Nessas emissões, detecta-se a opinião do enunciador e suas relações persuasivas com o co-enunciador:

-valoriza o primordial, o original: "A maior prenda, que há, é ser virgem.” (ROSA, 1967, p. 45, parágrafo 1 )

-declara a impotência dos seres: "Mas, primeiro, os outros obram a história da gente." (ROSA, 1967, p. 45, parágrafo 2)

-aponta a desvalorização do ser e a prevalência da materialidade: "Só que o que mais cedo reponta é a pobreza.” (ROSA, 1967, p. 45, parágrafo 3)

-revela a contradição entre o parecer estereotipado e o ser: "A gente tem é de ser miúda, mansa, feito botão de flor.” (ROSA, 1967, p. 45, parágrafo 5)

-chama a atenção para uma cadeia de ações e reações: "Por sopro do demo, se vê, uns homens caçam é mesmo isso, que inventam. Esses Lopes! - com eles, nenhum capim, nenhum leite.” (ROSA, 1967, p. 46, parágrafo 8)

-afirma a subjetividade das interações: "Dito: meio se escuta, dobro se entende." (ROSA, 1967, p. 46, parágrafo 14)

-assinala a ambivalência: “Tudo o que é bom faz mal e bem.” (ROSA, 1967, p. 47, parágrafo 20)

-desvaloriza o poder: "Todo o mundo vive para ter alguma serventia. Lopes, não! - desses me arrenego.” (ROSA, 1967, p. 48, parágrafo 22)

$\mathrm{Na}$ voz de Flausina, as expressões soam como paradoxo, à medida que suas ações também destroem. Na voz do enunciador, induz a inferir as declarações sobre ação e reação mencionadas no parágrafo 8 (ROSA, 1967, p. 46).

Relacionando-se essas expressões àquelas do nível actancial, também identificadoras do enunciador, surge a valorização de um estado integral, primordial dos seres, em detrimento de todo um complexo de poder que se sobrepõe e destrói.

\section{Espacialização}

A figura casa aparece entre as preferenciais e se relaciona a Flausina em:

A cavalo ele passava, por frente de casa, (ROSA, 1967, p. 45, parágrafo 5) Para me vigiar, botou uma preta magra em casa, (ROSA, 1967, p. 46, parágrafo 9)

Varri casa, joguei o cisco para a rua, (ROSA, 1967, p. 8, parágrafo 14)

Já entrava por mim a dentro em casa. (ROSA, 1967, 47, parágrafo 16) 
Nicão a casa rodeava. (ROSA, 1967, p. 47, parágrafo 17)

No que se refere à ocupação do espaço, emerge um corpo de pouco trânsito externo, pouco expandido, concentrado. Figurativizações aí expostas, especificamente passar a cavalo, deixam subentender o ambiente rural, que também se mostra nos relatos do tempo não-concomitante ou quando há comparações:

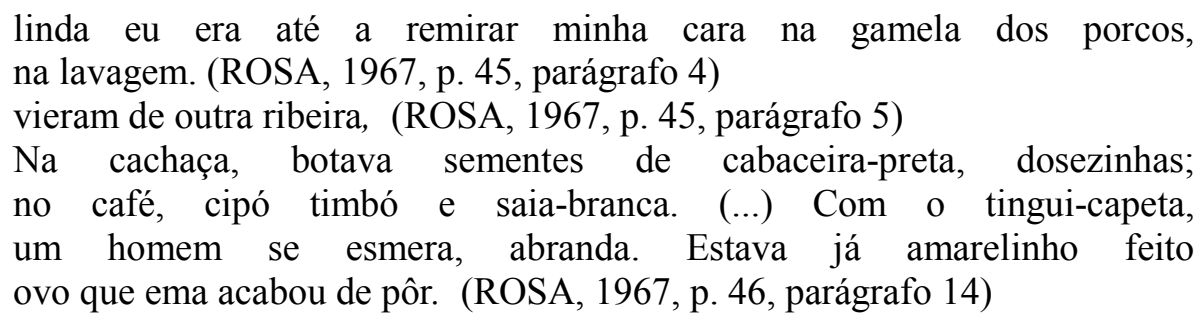

O espaço aqui, determinado pela debreagem enunciativa de primeiro grau, é assumido pelo narrador actante figurativizado em Flausina, para indicar o distanciamento imposto aos filhos, desconstruindo assim um consenso cultural. Também é com essa referência espacial que mostra a libertação:

para longe daqui viajarem gado. (ROSA, 1967, p. 48, parágrafo 21)

não fosse Deus, e até hoje mandavam aqui, donos. (ROSA, 1967, p. 45, parágrafo 5)

O fato de Flausina citar Deus, instala novamente o contraditório, pois, pela interdiscursividade, suas ações se colocam no oposto do que é recomendado em nome do Deus que menciona. Com Flausina, constroem-se dois percursos de valores: um, ligado ao consenso do que é o bem; outro, que remete ao oposto, criando contornos imprecisos. Flausina faz referências ao bem, mas desenvolve uma linha actancial considerada divergente. Essas contradições, quando vistas a partir da enunciação e do enunciador, adquirem o valor da denúncia e da conscientização.

A rejeição aos Lopes também pode ser traduzida em movimentos espaciais:

-recusa à aproximação: “Lopes nenhum me venha,” (ROSA, 1967, p. 45, parágrafo 1)

-movimento direcional oposto à progressão convencional, indicando distanciamento temporal e repúdio: "Para trás, o que passei," (ROSA, 1967, p. 45, parágrafo 1)

-compressão do corpo, representativos da opressão, e desejo de liberdade:

de se estar noite inteira em canto de catre, com o volume do outro cercando a gente, $[\ldots]$ com o abafo daquele, sempre rente, [...] Eu ficava espremida, mais pequena. Na parede minha unha riscava rezas, o querer outras larguras. (ROSA, 1967, p. 46, parágrafo 10)

\section{Figuras e temas}

A semântica do nível discursivo tem, a partir da figura Lopes, toda uma articulação explícita e também constitutiva, que põe em relevo o tema da dominação, da sujeição violenta e cruel e que se ratifica na própria etimologia da palavra. Essa arquitetura 
temática encontra nas figuras contidas na lista dos hápax a maioria de suas realizações, comprovando a importância desse rol na orientação do discurso. A oposição a partir de que o texto se erige acha-se nas figuras livre e sujeição, respectivamente os hápax 134 e 157 de sua TDVL, parcialmente exposta nos anexos deste artigo. O primeiro remete ao termo liberdade do nível fundamental, que também representa o objeto valor de Flausina e induz às nuances que adquire no discurso, quando relacionado às frustrações de Flausina, expressas nas figuras menininha - hápax 181; saudades - hápax 293; virgem - hápax 291. O antropônimo faz parte dos hápax, sob o número de ordem 136, bem como a representação de sua vulnerabilidade, com os hápax 138 - flor, 137 - flores, 129 - inocência, e sua rejeição à identidade frágil, hápax 180 - maria-miss. A transformação de Flausina é dada por entendi, hápax 102; saquei, 230; regi, 242; aprendi, 34; alisar, 50; herdei, 144; acabou, 66; lição, 127 ; de-cá -254 ; enriquecia - 112 ; autorizei - 37 ; mealhava -192 ; desforrada -92 . As referências aos anti-sujeitos também pertencem aos hápax, ratificando a importância desse rol lexical para a articulação do discurso: Sorocabano Lopes - 300; Zé - 99; primo - 316 e velhoco - 306. O período de opressão é figurativizado com os hápax 62 - abafo, 64 abusos, 78 - espremida, 79, 114 -emprazou; 120 - larguras.

$\mathrm{O}$ fato de o enunciador optar por um narrador actante feminino e ambientá-lo no espaço rural, traz figurativizações específicas para a caracterização de Flausina, muitas delas pertencentes também à lista dos hápax: 27 - bom-bocado ("Quero o bom-bocado que não fiz,", ROSA, 1967, p. 48, parágrafo 22); 49 - couve, 143 - fininho, 169 - picar ("picar fininho a couve.", ROSA, 1967, p. 47, parágrafo 16); 65 - abotoar ("abotoar botão na casa errada", ROSA, 1967, p. 47, parágrafo 19); 95 - ema, 200 - ovo ("feito ovo que ema acabou de pôr.", ROSA, 1967, p. 46, parágrafo 14); 104 - enxoval, 190 - noivado (" eu queria enxoval, ao menos, feito as outras, ilusão de noivado", ROSA, 1967, p. 45, parágrafo 7); 121 - lavagem, 320 - porcos ("a remirar minha cara na gamela dos porcos, na lavagem", ROSA, 1967, p. 45, parágrafo 3); 122 - leite (com eles, nenhum capim, nenhum leite.", ROSA $<1967$, p.46, parágrafo 8); 168 - temperadas, 277 - comidas ("temperadas comidas,", ROSA, 1967, p. 47, parágrafo 20); 140 - ferver, 205 - panela (“água de ferver fora de panela", ROSA, 1967, p. 47, parágrafo 18); 187 - pedacinhos ("Aos pedacinhos, me alembro.", ROSA, 1967, p.45, parágrafo 6); 255 - debruçada ("Sorria debruçada em janela,", ROSA, 1967, p. 47, parágrafo 18); 284 - camisolas ("camisolas do demônio", ROSA, 1967, p. 46, parágrafo 9); 313 - varri ("Varri casa,", ROSA, 1967, p.46, parágrafo14).

Por meio de Flausina desenham-se a sujeição e o repúdio. Entretanto, cria-se um contraste entre os atributos iniciais de delicadeza, sentimento e sensibilidade, e as ações desenvolvidas que não se destinam somente à libertação do jugo, mas também à apropriação de bens. Configuram-se o paradoxo e a ironia em que o caráter de delicadeza emerge como estereótipo aplicado à mulher, abordagem que se ratifica à medida que Flausina desconstrói valores como maternidade, honra e família, justificando como vingança pela violência sofrida. A figura assume o papel de justiceira:

Mãe e pai não deram para punir por mim. (ROSA, 1967, p.45, parágrafo 5)

Total, o quanto que era dele, cobrei, passando ligeiro já para minhas posses; até honra. (ROSA, 1967, p. 47, parágrafo 17)

Sorria debruçada em janela, no bico do beiço, negociável; justiçosa. (ROSA, 1967, p. 47, parágrafo 18)

Entanto que enfim, agora, desforrada, (ROSA, 1967, p. 48, parágrafo 21) 
Ratifica esse percurso o antropônimo Flausina, que traz uma referência à flor e que é rejeitado pela narradora actante:

Eu queria me chamar Maria Miss, reprovo meu nome, de Flausina.(ROSA, 1967 , p. 45, parágrafo 3 )

A justiça de Flausina não desfaz a frustração, porque não elimina sua experiência com os Lopes e não possibilita recuperar a época primeira da existência.

Tão certo como eu hoje estou o que nunca fui. (ROSA, 1967, p. 46, parágrafo 10)

De que me adianta estar remediada e entendida, se não dou conta da questão das saudades? $\mathrm{Eu}$, um dia, fui já muito menininha... (ROSA, 1967, 48, parágrafo 22).

Emerge a denúncia, não da mulher rural em relação ao poder representado pelos Lopes, mas do enunciador em relação a um mundo em que voracidade e insensibilidade se sobrepõem a todos os seres, impregnando-os e marcando suas interações.

A afirmação "A maior prenda, que há, é ser virgem” (ROSA, 1967, p. 45, parágrafo 1) e a indagação acompanhada de reminiscências - "De que me adianta estar remediada e entendida, se não dou conta da questão das saudades? $\mathrm{Eu}$, um dia, fui já muito menininha [...]" (ROSA, 1967, p. 48, parágrafo 22) - determinam um movimento para as origens: há concordância entre enunciador, narrador actante e ator na valorização dos planos naturais e genuínos dos seres. Por conseguinte, há um ethos voltado para esses planos, para a preservação e a integralidade em detrimento das construções e das ações destruidoras. A articulação de uma cena de denúncia, na qual, de modo concentrado, uma corporalidade feminina e madura expressa a sua perspectiva, já é uma ruptura com os estereótipos, principalmente quando o espaço é considerado. Significa romper o silêncio conformado, eleger a experiência com a tirania, para assinalar a violência de um poder que destrói a integridade, estimulando desejos iguais e ações insensíveis. Nesse percurso temático e figurativo, a estereotipia, relacionada à delicadeza, ao sentimento e à sensibilidade feminina, entra em contraste com a mulher justiceira, chamando a atenção para a voracidade e a crueldade existentes, estimuladas pelas próprias construções dos seres. A oposição de base, dominação x liberdade, diz respeito à libertação de criações sociais e culturais, e o possível encontro com o genuíno, a integralidade e a integridade ("A maior prenda, que há, é ser virgem.", ROSA, 1967, p. 45, parágrafo 1).

\section{Considerações finais}

Os dados fornecidos pela Tabela de Discriminação de Valores Lexicais mostraram-se válidos e produtivos; as observações desenvolvidas ao longo da descrição e da análise nasceram com os itens privilegiados pelos valores da TDVL, produzida pelo Método Camlong: itens preferenciais como o patronímico Lopes, o antropônimo Flausina, o adjetivo livre e o substantivo sujeição, inseridos no percurso gerativo, determinaram as operações de base, os programas narrativos e, transformados em figuras e temas relacionados pela articulação discursiva, delinearam as isotopias dominantes, impulsionando os comentários. $\mathrm{O}$ valor destacado de formas verbais flexionadas no presente do indicativo revelaram, nas frases de caráter geral, a presença do enunciador e a intencionalidade estimuladora do ato de comunicação. Em todos os procedimentos, a contribuição da tecnologia e da estatística para o 
desenvolvimento do percurso gerativo de sentido demonstrou a sua validade, criando a sugestão de um método interdisciplinar para descrição e análise de textos.

\section{Referências Bibliográficas}

BARROS, Diana Luz Pessoa de. Teoria Semiótica do Texto. São Paulo: Ática, 2005, 96 p. 2002, 174 pp.

.Teoria do Discurso. Fundamentos Semióticos. São Paulo: Humanitas FFLCH/USP,

- Paixões e Apaixonados: Exame Semiótico de Alguns Percursos in: Cruzeiro Semiótico, Porto, n. 16, p. 11-24, 1992.

. Estudos do Discurso. In: FIORIN, José Luiz (org.). Introdução à Lingüística II. Princípios de Análise, 2a . ed. São Paulo: Contexto, p. 187-219.

. \& FIORIN, José Luiz (orgs.) Dialogismo, Polifonia, Intertextualidade. São Paulo:

Edusp, 2003, 96 pp.

BORBA, F. Silva. Dicionário de Usos do Português do Brasil. São Paulo: Ática, 2002, 1674 pp.

CAMLONG, André. Methode d'Analyse Lexicale, Textuelle et Discursive. Paris: Ophrys, 1996, $231 \mathrm{pp}$.

DURAND, Gilbert. Estruturas Antropológicas do Imaginário. São Paulo: Martins Fontes, 1997, $552 \mathrm{pp}$.

A Imaginação Simbólica. São Paulo: Cultrix,1988, 114 pp.

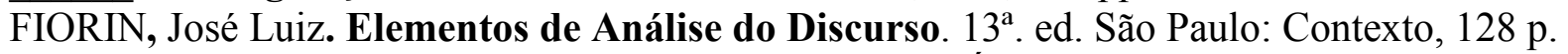
. As Astúcias da Enunciação. 1ª . ed. São Paulo: Ática, 320 pp.

- Algumas Considerações sobre o Medo e a Vergonha. In: Cruzeiro Semiótico, Porto, no. 16, 55-63, 1992.

FONTANille, J. \& GREIMAS, A.J. Semiótica das Paixões. São Paulo: Ática, 1993, 294 pp.

GREIMAS, Algirdas Julien. Sobre o Sentido: Ensaios Semióticos. Petrópolis-RJ: Vozes, 1975, $245 \mathrm{pp}$.

.\& COURTES, Joseph. Dicionário de Semiótica. São Paulo: Cultrix, 1989, 493 pp.

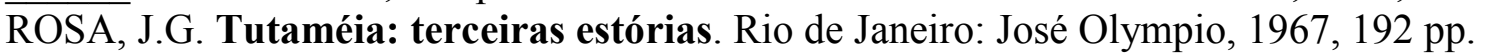

ZAPPAROLI, Zilda M. \& CAMLONG, André. Do Léxico ao Discurso pela Informática. São Paulo: EDUSP/FAPESP, 2002, 256 pp. 


\author{
ANEXOS \\ Anexo A: Variável
}

Esses Lopes

$1 \quad$ Má gente, de má paz; deles, quero distantes léguas. Mesmo de meus filhos, os três. Livre, por velha nem revogada não me dou, idade é a qualidade. Amo um homem, ele vive de admirar meus bons préstimos, boca cheia d' água. Meu gosto agora é ser feliz, em uso, no sofrer e no regalo. Quero falar alto. Lopes nenhum me venha, que às dentadas escorraço. Para trás, o que passei, foi arremedando e esquecendo. Ainda achei o fundo do meu coração. A maior prenda, que há, é ser virgem.

2 Mas, primeiro, os outros obram a história da gente.

3 Eu era menina, me via vestida de flores. Só que o que mais cedo reponta é pobreza. Me valia ter pai e mãe, sendo órfã de dinheiro? Mocinha fiquei, sem da inocência me destruir, tirava junto cantigas de roda e modinhas de sentimento. Eu queria me chamar Maria-Miss, reprovo meu nome, de Flausina.

4 Deus me deu esta pintinha preta na alvura do queixo - linda eu era até a remirar minha cara na gamela dos porcos, na lavagem. E veio aquele, Lopes, chapéu grandão, aba desabada. Nenhum presta; mas esse, Zé, o pior, rompente sedutor. Me olhava: aí eu espiada e enxergada, no ter de me estremecer.

5 A cavalo ele passava, por frente de casa, meu pai e minha mãe saudavam, soturnos de outro jeito. Esses Lopes, raça, vieram de outra ribeira, tudo adquiriam ou tomavam; não fosse Deus, e até hoje mandavam aqui, donos. A gente tem é de ser miúda, mansa, feito botão de flor. Mãe e pai não deram para punir por mim.

6 Aos pedacinhos, me alembro.

7 Mal com dilato para chorar, eu queria enxoval, ao menos, feito as outras, ilusão de noivado. Tive algum? Cortesias nem igreja. O homem me pegou, com quentes mãos e curtos braços, me levou para uma casa, para a cama dele. Mais aprendi a lição de ter juízo. Calei muitos prantos. Agüentei aquele caso corporal.

8 Fiz que quis: saquei malignas lábias. Por sopro do demo, se vê, uns homens caçam é mesmo isso, que inventam. Esses Lopes! - com eles, nenhum capim, nenhum leite. Falei, quando dinheiro me deu, afetando ser bondoso: - "Eu tinha três vinténs, agora tenho quatro..." Contentado ele ficou, não sabia que eu estava abrindo e medindo.

9 Para me vigiar, botou uma preta magra em casa, Si-Ana. Entendi: a que eu tinha de engambelar, por arte de contas; e à qual chamei de madrinha e comadre. Regi de alisar por fora a vida. Deitada é que eu achava o somenos do mundo, camisolas do demônio.

10 Ninguém põe idéia nesses casos: de se estar noite inteira em canto de catre, com o volume do outro cercando a gente, rombudo, o cheiro, o ressonar, qualquer um é alheios abusos. A gente, eu, delicada moça, cativa assim, com o abafo daquele, sempre rente, no escuro. Daninhagem, o homem parindo os ocultos pensamentos, como um dia come o outro, sei as perversidades que roncava? Aquilo tange as canduras de noiva, pega feito doença, para a gente em espírito se traspassa. Tão certo como eu hoje estou o que nunca fui. Eu ficava espremida mais pequena, na parede minha unha riscava rezas, o querer outras larguras.

11 Tracei as letras. Carecia de ter o bem ler e escrever, conforme escondida. Isso principiei - minha ajuda em jornais de embrulhar e mais com as crianças de escola.

12 E dê-cá dinheiro.

13 O que podendo, dele tudo eu para mim regrava. Mealhava. Fazia portar escrituras. Sem acautelar, ele me enriquecia. Mais, enfim que o filho dele nasceu, agora já tinha em mim a confiança toda, quase. Mandou embora a preta Si-Ana, quando levantei o falso alegado: que ela alcovitava eu cedesse vezes carnais a outro, Lopes igual - que da vida logo desapareceu, em sistema de não-se-sabe.

14 Dito: meio se escuta, dobro se entende. Virei cria de cobra. Na cachaça, botava sementes de cabaceira-preta, dosezinhas; no café, cipó-timbó e saia- 
branca. Só para arrefecer aquela desatada vontade, nem confirmo que seja crime. Com o tingui-capeta, um homem se esmera, abranda. Estava já amarelinho, feito ovo que ema acabou de pôr. Sem muito custo, morreu. Minha vida foi muito fatal. Varri casa, joguei o cisco para a rua, depois do enterro.

15 E os Lopes me davam sossego?

16 Dois deles, tesos, me requerendo, o primo e o irmão do falecido. Mexi em vão por me soltar, dessas minhas pintadas feras. Nicão, um, mau me emprazou: "Despois da missa de mês, me espera..." Mas o Sertório, senhor, o outro, ouro e punhal em mão, inda antes do sétimo dia já entrava por mim a dentro em casa. Padeci com jeito. E o governo da vida? Anos, que me foram, de gentil sujeição, custoso que nem guardar chuva em cabaça, picar fininho a couve.

17 Tanto na bramosia os dois tendo ciúme. Tinham de ter, autorizei. Nicão a casa rodeava. Ao Sertório dei mesmo dois filhos? Total, o quanto era dele, cobrei, passando ligeiro já para minhas posses; até honra. Experimentei finuras novas somente em jardim de mim, sozinha. Tomei ar de mais donzela.

18 Sorria debruçada em janela, no bico do beiço, negociável; justiçosa. Até que aquela idéia endurecesse. Eu já sabia que ele era Lopes, desatinado, fogoso, água de ferver fora de panela. Vi foi ele sair, fulo de fulo, revestido de raiva, com os bolsos cheios de calúnias. Ao outro eu tinha enviado os recados, embebidos em doçuras. Ri muito útil ultimamente. Se enfrentaram, bom contra bom, meus relâmpagos, a tiros e ferros. Nicão morreu sem demora. O Sertório durou, uns dias. Inconsolável chorei, conforme os costumes certos, por a piedade de todos: pobre, duas e meio três vezes viúva. Na beira do meu terreiro.

19 Mas um, mais, porém, ainda me sobrou. Sorocabano Lopes, velhoco, o das fortes propriedades. Me viu e me botou na cabeça. Aceitei, de boa graça, ele era o aflitinho dos consolos. Eu impondo: - "De hoje por diante, só muito casada!" Ele, por fervor, concordou - com o que, para homem nessa idade inferior, é abotoar o botão na casa errada. E, este, bem demais e melhor tratei, seu desejo efetuado.

20 Por isso, andei quebrando metade da cabeça: dava a ele gordas, temperadas comidas, e sem descanso agradadas horas - o sujeito chupado de amores, de chuchurro. Tudo que é bom faz mal e bem. Quem morreu mais foi ele. Daí, tudo tanto herdei, até que com nenhum enjôo.

21 Entanto que enfim, agora, desforrada. O povo ruim terminou, aqueles. Meus filhos, Lopes, também, provi de dinheiro, para longe daqui viajarem gado. Deixo de porfias, com o amor que achei. Duvido, discordo de quem não goste. Amo, mesmo. Que podia ser mãe dele, menos me falem, sou de me constar em folhinhas e datas?

22 Que em meu corpo ele não mexa fácil. Mas que, por bem de mim, me venham filhos, outros, modernos e acomodados. Quero o bom-bocado que não fiz, quero gente sensível. De que me adianta estar remediada e entendida, se não dou conta de questão de saudades? Eu, um dia, fui já muito menininha... Todo o mundo vive para ter alguma serventia. Lopes, não! - desses me arrenego.

(ROSA, J. G. Tutaméia: terceiras histórias. Rio de Janeiro: Nova Fronteira, 1985, pp. 72-75). 
CASA, Vol.7 n.1, julho de 2009

\section{Anexo B}

Faixa Preferencial da Tabela de Discriminação de Valores Lexicais TDVL

ESSES LOPES

\begin{tabular}{|c|c|c|c|c|}
\hline Ordem & Itens Lexicais & Total & Esses Lopes & Valor \\
\hline 1 & lopes & 10 & 10 & 8,148 \\
\hline 2 & nicão & 3 & 3 & 4,463 \\
\hline 3 & sertório & 3 & 3 & 4,463 \\
\hline 4 & preta & 3 & 3 & 4,463 \\
\hline 5 & filhos & 5 & 4 & 4,436 \\
\hline 6 & quero & 5 & 4 & 4,436 \\
\hline 7 & morreu & 4 & 3 & 3,671 \\
\hline 8 & si-ana & 2 & 2 & 3,644 \\
\hline 9 & botão & 2 & 2 & 3,644 \\
\hline 10 & amo & 2 & 2 & 3,644 \\
\hline 11 & deus & 2 & 2 & 3,644 \\
\hline 12 & fulo & 2 & 2 & 3,644 \\
\hline 13 & má & 2 & 2 & 3,644 \\
\hline 14 & achei & 2 & 2 & 3,644 \\
\hline 15 & meus & 7 & 4 & 3,456 \\
\hline 16 & outro & 14 & 6 & 3,302 \\
\hline 17 & nenhum & 11 & 5 & 3,183 \\
\hline 18 & esses & 5 & 3 & 3,110 \\
\hline 19 & hoje & 5 & 3 & 3,110 \\
\hline 20 & dinheiro & 8 & 4 & 3,095 \\
\hline 21 & idade & 3 & 2 & 2,751 \\
\hline 22 & botou & 3 & 2 & 2,751 \\
\hline 23 & dou & 3 & 2 & 2,751 \\
\hline 24 & $\mathrm{me}$ & 140 & 29 & 2,675 \\
\hline 25 & bolsos & 1 & 1 & 2,577 \\
\hline 26 & bondoso & 1 & 1 & 2,577 \\
\hline 27 & bom-bocado & 1 & 1 & 2,577 \\
\hline 28 & bico & 1 & 1 & 2,577 \\
\hline 29 & agradadas & 1 & 1 & 2,577 \\
\hline 30 & admirar & 1 & 1 & 2,577 \\
\hline 31 & afetando & 1 & 1 & 2,577 \\
\hline 32 & adquiriam & 1 & 1 & 2,577 \\
\hline 33 & aflitinho & 1 & 1 & 2,577 \\
\hline 34 & aprendi & 1 & 1 & 2,577 \\
\hline 35 & adianta & 1 & 1 & 2,577 \\
\hline 36 & acomodados & 1 & 1 & 2,577 \\
\hline 37 & autorizei & 1 & 1 & 2,577 \\
\hline 38 & abranda & 1 & 1 & 2,577 \\
\hline 39 & arte & 1 & 1 & 2,577 \\
\hline 40 & botava & 1 & 1 & 2,577 \\
\hline 41 & bons & 1 & 1 & 2,577 \\
\hline 42 & cabaceira-preta & 1 & 1 & 2,577 \\
\hline 43 & arrenego & 1 & 1 & 2,577 \\
\hline 44 & bramosia & 1 & 1 & 2,577 \\
\hline 45 & arrefecer & 1 & 1 & 2,577 \\
\hline 46 & abrindo & 1 & 1 & 2,577 \\
\hline
\end{tabular}


CASA, Vol.7 n.1, julho de 2009

\begin{tabular}{|c|c|c|c|c|}
\hline 47 & corporal & 1 & 1 & 2,577 \\
\hline 48 & cortesias & 1 & 1 & 2,577 \\
\hline 49 & couve & 1 & 1 & 2,577 \\
\hline 50 & alisar & 1 & 1 & 2,577 \\
\hline 51 & amarelinho & 1 & 1 & 2,577 \\
\hline 52 & cachaça & 1 & 1 & 2,577 \\
\hline 53 & caçam & 1 & 1 & 2,577 \\
\hline 54 & contentado & 1 & 1 & 2,577 \\
\hline 55 & crime & 1 & 1 & 2,577 \\
\hline 56 & cria & 1 & 1 & 2,577 \\
\hline 57 & crianças & 1 & 1 & 2,577 \\
\hline 58 & constar & 1 & 1 & 2,577 \\
\hline 59 & consolos & 1 & 1 & 2,577 \\
\hline 60 & alvura & 1 & 1 & 2,577 \\
\hline 61 & acautelar & 1 & 1 & 2,577 \\
\hline 62 & abafo & 1 & 1 & 2,577 \\
\hline 63 & $a b a$ & 1 & 1 & 2,577 \\
\hline 64 & abusos & 1 & 1 & 2,577 \\
\hline 65 & abotoar & 1 & 1 & 2,577 \\
\hline 66 & acabou & 1 & 1 & 2,577 \\
\hline 67 & alegado & 1 & 1 & 2,577 \\
\hline 68 & alheios & 1 & 1 & 2,577 \\
\hline 69 & alcovitava & 1 & 1 & 2,577 \\
\hline 70 & amores & 1 & 1 & 2,577 \\
\hline 71 & agüentei & 1 & 1 & 2,577 \\
\hline 72 & ajuda & 1 & 1 & 2,577 \\
\hline 73 & andei & 1 & 1 & 2,577 \\
\hline 74 & escola & 1 & 1 & 2,577 \\
\hline 75 & esmera & 1 & 1 & 2,577 \\
\hline 76 & esquecendo & 1 & 1 & 2,577 \\
\hline 77 & estremecer & 1 & 1 & 2,577 \\
\hline 78 & espremida & 1 & 1 & 2,577 \\
\hline 79 & espiada & 1 & 1 & 2,577 \\
\hline 80 & espírito & 1 & 1 & 2,577 \\
\hline 81 & falecido & 1 & 1 & 2,577 \\
\hline 82 & falem & 1 & 1 & 2,577 \\
\hline 83 & distantes & 1 & 1 & 2,577 \\
\hline 84 & donzela & 1 & 1 & 2,577 \\
\hline 85 & donos & 1 & 1 & 2,577 \\
\hline 86 & destruir & 1 & 1 & 2,577 \\
\hline 87 & dobro & 1 & 1 & 2,577 \\
\hline 88 & dosezinhas & 1 & 1 & 2,577 \\
\hline 89 & dilato & 1 & 1 & 2,577 \\
\hline 90 & desejo & 1 & 1 & 2,577 \\
\hline 91 & discordo & 1 & 1 & 2,577 \\
\hline 92 & desforrada & 1 & 1 & 2,577 \\
\hline 93 & escuta & 1 & 1 & 2,577 \\
\hline 94 & escrituras & 1 & 1 & 2,577 \\
\hline 95 & ema & 1 & 1 & 2,577 \\
\hline 96 & escorraço & 1 & 1 & 2,577 \\
\hline 97 & escrever & 1 & 1 & 2,577 \\
\hline 98 & escondida & 1 & 1 & 2,577 \\
\hline
\end{tabular}


CASA, Vol.7 n.1, julho de 2009

\begin{tabular}{|c|c|c|c|c|}
\hline 99 & zé & 1 & 1 & 2,577 \\
\hline 100 & enviado & 1 & 1 & 2,577 \\
\hline 101 & enxergada & 1 & 1 & 2,577 \\
\hline 102 & entendi & 1 & 1 & 2,577 \\
\hline 103 & entendida & 1 & 1 & 2,577 \\
\hline 104 & enxoval & 1 & 1 & 2,577 \\
\hline 105 & errada & 1 & 1 & 2,577 \\
\hline 106 & embebidos & 1 & 1 & 2,577 \\
\hline 107 & experimentei & 1 & 1 & 2,577 \\
\hline 108 & embrulhar & 1 & 1 & 2,577 \\
\hline 109 & efetuado & 1 & 1 & 2,577 \\
\hline 110 & durou & 1 & 1 & 2,577 \\
\hline 111 & duvido & 1 & 1 & 2,577 \\
\hline 112 & enriquecia & 1 & 1 & 2,577 \\
\hline 113 & enjôo & 1 & 1 & 2,577 \\
\hline 114 & emprazou & 1 & 1 & 2,577 \\
\hline 115 & engambelar & 1 & 1 & 2,577 \\
\hline 116 & enfrentaram & 1 & 1 & 2,577 \\
\hline 117 & endurecesse & 1 & 1 & 2,577 \\
\hline 118 & contas & 1 & 1 & 2,577 \\
\hline 119 & ligeiro & 1 & 1 & 2,577 \\
\hline 120 & larguras & 1 & 1 & 2,577 \\
\hline 121 & lavagem & 1 & 1 & 2,577 \\
\hline 122 & leite & 1 & 1 & 2,577 \\
\hline 123 & ler & 1 & 1 & 2,577 \\
\hline 124 & letras & 1 & 1 & 2,577 \\
\hline 125 & levantei & 1 & 1 & 2,577 \\
\hline 126 & levou & 1 & 1 & 2,577 \\
\hline 127 & lição & 1 & 1 & 2,577 \\
\hline 128 & lábias & 1 & 1 & 2,577 \\
\hline 129 & inocência & 1 & 1 & 2,577 \\
\hline 130 & madrinha & 1 & 1 & 2,577 \\
\hline 131 & malignas & 1 & 1 & 2,577 \\
\hline 132 & magra & 1 & 1 & 2,577 \\
\hline 133 & mandavam & 1 & 1 & 2,577 \\
\hline 134 & livre & 1 & 1 & 2,577 \\
\hline 135 & fogoso & 1 & 1 & 2,577 \\
\hline 136 & flausina & 1 & 1 & 2,577 \\
\hline 137 & flores & 1 & 1 & 2,577 \\
\hline 138 & flor & 1 & 1 & 2,577 \\
\hline 139 & ferros & 1 & 1 & 2,577 \\
\hline 140 & ferver & 1 & 1 & 2,577 \\
\hline 141 & fervor & 1 & 1 & 2,577 \\
\hline 142 & finuras & 1 & 1 & 2,577 \\
\hline 143 & fininho & 1 & 1 & 2,577 \\
\hline 144 & herdei & 1 & 1 & 2,577 \\
\hline 145 & honra & 1 & 1 & 2,577 \\
\hline 146 & história & 1 & 1 & 2,577 \\
\hline 147 & gado & 1 & 1 & 2,577 \\
\hline 148 & folhinhas & 1 & 1 & 2,577 \\
\hline 149 & fortes & 1 & 1 & 2,577 \\
\hline 150 & filho & 1 & 1 & 2,577 \\
\hline
\end{tabular}


CASA, Vol.7 n.1, julho de 2009

\begin{tabular}{|c|c|c|c|c|}
\hline 151 & tiros & 1 & 1 & 2,577 \\
\hline 152 & terreiro & 1 & 1 & 2,577 \\
\hline 153 & tingui-capeta & 1 & 1 & 2,577 \\
\hline 154 & serventia & 1 & 1 & 2,577 \\
\hline 155 & sétimo & 1 & 1 & 2,577 \\
\hline 156 & sistema & 1 & 1 & 2,577 \\
\hline 157 & sujeição & 1 & 1 & 2,577 \\
\hline 158 & tesos & 1 & 1 & 2,577 \\
\hline 159 & sofrer & 1 & 1 & 2,577 \\
\hline 160 & sobrou & 1 & 1 & 2,577 \\
\hline 161 & jornais & 1 & 1 & 2,577 \\
\hline 162 & joguei & 1 & 1 & 2,577 \\
\hline 163 & inteira & 1 & 1 & 2,577 \\
\hline 164 & justiçosa & 1 & 1 & 2,577 \\
\hline 165 & inda & 1 & 1 & 2,577 \\
\hline 166 & inconsolável & 1 & 1 & 2,577 \\
\hline 167 & tange & 1 & 1 & 2,577 \\
\hline 168 & temperadas & 1 & 1 & 2,577 \\
\hline 169 & picar & 1 & 1 & 2,577 \\
\hline 170 & juízo & 1 & 1 & 2,577 \\
\hline 171 & jardim & 1 & 1 & 2,577 \\
\hline 172 & inventam & 1 & 1 & 2,577 \\
\hline 173 & modinhas & 1 & 1 & 2,577 \\
\hline 174 & modernos & 1 & 1 & 2,577 \\
\hline 175 & mocinha & 1 & 1 & 2,577 \\
\hline 176 & moça & 1 & 1 & 2,577 \\
\hline 177 & miúda & 1 & 1 & 2,577 \\
\hline 178 & missa & 1 & 1 & 2,577 \\
\hline 179 & mansa & 1 & 1 & 2,577 \\
\hline 180 & maria-miss & 1 & 1 & 2,577 \\
\hline 181 & menininha & 1 & 1 & 2,577 \\
\hline 182 & menina & 1 & 1 & 2,577 \\
\hline 183 & passei & 1 & 1 & 2,577 \\
\hline 184 & metade & 1 & 1 & 2,577 \\
\hline 185 & mexa & 1 & 1 & 2,577 \\
\hline 186 & mexi & 1 & 1 & 2,577 \\
\hline 187 & pedacinhos & 1 & 1 & 2,577 \\
\hline 188 & mês & 1 & 1 & 2,577 \\
\hline 189 & não-se-sabe & 1 & 1 & 2,577 \\
\hline 190 & noivado & 1 & 1 & 2,577 \\
\hline 191 & medindo & 1 & 1 & 2,577 \\
\hline 192 & mealhava & 1 & 1 & 2,577 \\
\hline 193 & nesses & 1 & 1 & 2,577 \\
\hline 194 & novas & 1 & 1 & 2,577 \\
\hline 195 & negociável & 1 & 1 & 2,577 \\
\hline 196 & nasceu & 1 & 1 & 2,577 \\
\hline 197 & padeci & 1 & 1 & 2,577 \\
\hline 198 & grandão & 1 & 1 & 2,577 \\
\hline 199 & parede & 1 & 1 & 2,577 \\
\hline 200 & ovo & 1 & 1 & 2,577 \\
\hline 201 & impondo & 1 & 1 & 2,577 \\
\hline 202 & gordas & 1 & 1 & 2,577 \\
\hline
\end{tabular}


CASA, Vol.7 n.1, julho de 2009

\begin{tabular}{|c|c|c|c|c|}
\hline 203 & goste & 1 & 1 & 2,577 \\
\hline 204 & gentil & 1 & 1 & 2,577 \\
\hline 205 & panela & 1 & 1 & 2,577 \\
\hline 206 & perversidades & 1 & 1 & 2,577 \\
\hline 207 & parindo & 1 & 1 & 2,577 \\
\hline 208 & ocultos & 1 & 1 & 2,577 \\
\hline 209 & ouro & 1 & 1 & 2,577 \\
\hline 210 & órfã & 1 & 1 & 2,577 \\
\hline 211 & ribeira & 1 & 1 & 2,577 \\
\hline 212 & ressonar & 1 & 1 & 2,577 \\
\hline 213 & revogada & 1 & 1 & 2,577 \\
\hline 214 & ri & 1 & 1 & 2,577 \\
\hline 215 & revestido & 1 & 1 & 2,577 \\
\hline 216 & rezas & 1 & 1 & 2,577 \\
\hline 217 & feras & 1 & 1 & 2,577 \\
\hline 218 & cheios & 1 & 1 & 2,577 \\
\hline 219 & chorei & 1 & 1 & 2,577 \\
\hline 220 & cheia & 1 & 1 & 2,577 \\
\hline 221 & chorar & 1 & 1 & 2,577 \\
\hline 222 & cobrei & 1 & 1 & 2,577 \\
\hline 223 & cisco & 1 & 1 & 2,577 \\
\hline 224 & cipó-timbó & 1 & 1 & 2,577 \\
\hline 225 & chupado & 1 & 1 & 2,577 \\
\hline 226 & cobra & 1 & 1 & 2,577 \\
\hline 227 & chuchurro & 1 & 1 & 2,577 \\
\hline 228 & ciúme & 1 & 1 & 2,577 \\
\hline 229 & sensível & 1 & 1 & 2,577 \\
\hline 230 & saquei & 1 & 1 & 2,577 \\
\hline 231 & rombudo & 1 & 1 & 2,577 \\
\hline 232 & rompente & 1 & 1 & 2,577 \\
\hline 233 & roncava & 1 & 1 & 2,577 \\
\hline 234 & remediada & 1 & 1 & 2,577 \\
\hline 235 & remirar & 1 & 1 & 2,577 \\
\hline 236 & reponta & 1 & 1 & 2,577 \\
\hline 237 & reprovo & 1 & 1 & 2,577 \\
\hline 238 & requerendo & 1 & 1 & 2,577 \\
\hline 239 & relâmpagos & 1 & 1 & 2,577 \\
\hline 240 & regrava & 1 & 1 & 2,577 \\
\hline 241 & regalo & 1 & 1 & 2,577 \\
\hline 242 & regi & 1 & 1 & 2,577 \\
\hline 243 & saudades & 1 & 1 & 2,577 \\
\hline 244 & sedutor & 1 & 1 & 2,577 \\
\hline 245 & saudavam & 1 & 1 & 2,577 \\
\hline 246 & riscava & 1 & 1 & 2,577 \\
\hline 247 & ruim & 1 & 1 & 2,577 \\
\hline 248 & deitada & 1 & 1 & 2,577 \\
\hline 249 & daninhagem & 1 & 1 & 2,577 \\
\hline 250 & curtos & 1 & 1 & 2,577 \\
\hline 251 & cativa & 1 & 1 & 2,577 \\
\hline 252 & casada & 1 & 1 & 2,577 \\
\hline 253 & casos & 1 & 1 & 2,577 \\
\hline 254 & dê-cá & 1 & 1 & 2,577 \\
\hline
\end{tabular}


CASA, Vol.7 n.1, julho de 2009

\begin{tabular}{|c|c|c|c|c|}
\hline 255 & debruçada & 1 & 1 & 2,577 \\
\hline 256 & davam & 1 & 1 & 2,577 \\
\hline 257 & datas & 1 & 1 & 2,577 \\
\hline 258 & confirmo & 1 & 1 & 2,577 \\
\hline 259 & custo & 1 & 1 & 2,577 \\
\hline 260 & demônio & 1 & 1 & 2,577 \\
\hline 261 & demo & 1 & 1 & 2,577 \\
\hline 262 & dentadas & 1 & 1 & 2,577 \\
\hline 263 & demora & 1 & 1 & 2,577 \\
\hline 264 & deram & 1 & 1 & 2,577 \\
\hline 265 & desabada & 1 & 1 & 2,577 \\
\hline 266 & delicada & 1 & 1 & 2,577 \\
\hline 267 & deixo & 1 & 1 & 2,577 \\
\hline 268 & custoso & 1 & 1 & 2,577 \\
\hline 269 & desapareceu & 1 & 1 & 2,577 \\
\hline 270 & descanso & 1 & 1 & 2,577 \\
\hline 271 & desatada & 1 & 1 & 2,577 \\
\hline 272 & carnais & 1 & 1 & 2,577 \\
\hline 273 & certos & 1 & 1 & 2,577 \\
\hline 274 & canduras & 1 & 1 & 2,577 \\
\hline 275 & concordou & 1 & 1 & 2,577 \\
\hline 276 & comadre & 1 & 1 & 2,577 \\
\hline 277 & comidas & 1 & 1 & 2,577 \\
\hline 278 & come & 1 & 1 & 2,577 \\
\hline 279 & cedo & 1 & 1 & 2,577 \\
\hline 280 & cedesse & 1 & 1 & 2,577 \\
\hline 281 & cercando & 1 & 1 & 2,577 \\
\hline 282 & catre & 1 & 1 & 2,577 \\
\hline 283 & cantigas & 1 & 1 & 2,577 \\
\hline 284 & camisolas & 1 & 1 & 2,577 \\
\hline 285 & calei & 1 & 1 & 2,577 \\
\hline 286 & calúnias & 1 & 1 & 2,577 \\
\hline 287 & cama & 1 & 1 & 2,577 \\
\hline 288 & traspassa & 1 & 1 & 2,577 \\
\hline 289 & tomavam & 1 & 1 & 2,577 \\
\hline 290 & tratei & 1 & 1 & 2,577 \\
\hline 291 & virgem & 1 & 1 & 2,577 \\
\hline 292 & viúva & 1 & 1 & 2,577 \\
\hline 293 & vinténs & 1 & 1 & 2,577 \\
\hline 294 & uso & 1 & 1 & 2,577 \\
\hline 295 & unha & 1 & 1 & 2,577 \\
\hline 296 & tracei & 1 & 1 & 2,577 \\
\hline 297 & sorria & 1 & 1 & 2,577 \\
\hline 298 & sopro & 1 & 1 & 2,577 \\
\hline 299 & somenos & 1 & 1 & 2,577 \\
\hline 300 & sorocabano-lopes & 1 & 1 & 2,577 \\
\hline 301 & soltar & 1 & 1 & 2,577 \\
\hline 302 & sossego & 1 & 1 & 2,577 \\
\hline 303 & soturnos & 1 & 1 & 2,577 \\
\hline 304 & sozinha & 1 & 1 & 2,577 \\
\hline 305 & velha & 1 & 1 & 2,577 \\
\hline 306 & velhoco & 1 & 1 & 2,577 \\
\hline
\end{tabular}


CASA, Vol.7 n.1, julho de 2009

\begin{tabular}{|c|c|c|c|c|}
\hline 307 & venham & 1 & 1 & 2,577 \\
\hline 308 & volume & 1 & 1 & 2,577 \\
\hline 309 & venha & 1 & 1 & 2,577 \\
\hline 310 & vi & 1 & 1 & 2,577 \\
\hline 311 & viajarem & 1 & 1 & 2,577 \\
\hline 312 & vestida & 1 & 1 & 2,577 \\
\hline 313 & varri & 1 & 1 & 2,577 \\
\hline 314 & pior & 1 & 1 & 2,577 \\
\hline 315 & posses & 1 & 1 & 2,577 \\
\hline 316 & primo & 1 & 1 & 2,577 \\
\hline 317 & principiei & 1 & 1 & 2,577 \\
\hline 318 & pintinha & 1 & 1 & 2,577 \\
\hline 319 & piedade & 1 & 1 & 2,577 \\
\hline 320 & porcos & 1 & 1 & 2,577 \\
\hline 321 & portar & 1 & 1 & 2,577 \\
\hline 322 & pintadas & 1 & 1 & 2,577 \\
\hline 323 & porfias & 1 & 1 & 2,577 \\
\hline 324 & sair & 1 & 1 & 2,577 \\
\hline 325 & saia-branca & 1 & 1 & 2,577 \\
\hline 326 & prenda & 1 & 1 & 2,577 \\
\hline 327 & presta & 1 & 1 & 2,577 \\
\hline 328 & prantos & 1 & 1 & 2,577 \\
\hline 329 & povo & 1 & 1 & 2,577 \\
\hline 330 & préstimos & 1 & 1 & 2,577 \\
\hline 331 & punir & 1 & 1 & 2,577 \\
\hline 332 & provi & 1 & 1 & 2,577 \\
\hline 333 & propriedades & 1 & 1 & 2,577 \\
\hline 334 & raça & 1 & 1 & 2,577 \\
\hline 335 & quebrando & 1 & 1 & 2,577 \\
\hline 336 & quentes & 1 & 1 & 2,577 \\
\hline 337 & sentimento & 1 & 1 & 2,577 \\
\hline 338 & qualidade & 1 & 1 & 2,577 \\
\hline 339 & punhal & 1 & 1 & 2,577 \\
\hline 340 & recados & 1 & 1 & 2,577 \\
\hline 341 & pôr & 1 & 1 & 2,577 \\
\hline 342 & até & 14 & 5 & 2,510 \\
\hline 343 & casa & 23 & 7 & 2,466 \\
\hline 344 & ter & 19 & 6 & 2,389 \\
\hline 345 & feito & 11 & 4 & 2,289 \\
\hline 346 & vive & 4 & 2 & 2,189 \\
\hline 347 & deles & 4 & 2 & 2,189 \\
\hline 348 & minhas & 4 & 2 & 2,189 \\
\hline 349 & conforme & 4 & 2 & 2,189 \\
\hline 350 & estar & 4 & 2 & 2,189 \\
\hline 351 & dele & 17 & 5 & 1,995 \\
\hline 352 & já & 22 & 6 & 1,972 \\
\hline
\end{tabular}

